\title{
Lithopanspermia - The Terrestrial Input During the Past 550 Million Years
}

\author{
Martin Beech ${ }^{1,2}$, Ian M. Coulson ${ }^{3}$, Mark Comte ${ }^{2}$ \\ ${ }^{1}$ Campion College, the University of Regina, Regina, Canada \\ ${ }^{2}$ Department Physics, the University of Regina, Regina, Canada \\ ${ }^{3}$ Department Geology, the University of Regina, Regina, Canada
}

Email address:

beechm@uregina.ca (M. Beech), ian.coulson@uregina.ca (I. M. Coulson), comte20m@uregina.ca (M. Comte)

\section{To cite this article:}

Martin Beech, Ian M. Coulson, Mark Comte. Lithopanspermia - The Terrestrial Input During the Past 550 Million Years. American Journal of Astronomy and Astrophysics. Vol. 6, No. 3, 2018, pp. 81-90. doi: 10.11648/j.ajaa.20180603.14

Received: September 18, 2018; Accepted: October 25, 2018; Published: November 27, 2018

\begin{abstract}
An estimate for the minimum amount of terrestrial material deposited into interplanetary space over the past $\sim 550$ million years is made. Using the published characteristics of known terrestrial impact craters, it is found that at least $10^{13} \mathrm{~kg}$ of potentially life-bearing matter has been ejected from the Earth's surface into the inner solar system. This estimate is derived upon a reverse-engineering approach which links the observed crater diameter to impactor size and which employs a set of analytic equations to obtain an estimate of the mass fraction of material ejected, with a speed greater than the Earth's escape velocity, during the crater-forming process. Of the total amount of terrestrial material ejected into the inner solar system, some $67 \%$ can be attributed to the formation of the Chicxulub crater - the largest known crater to have been produced within the Phanerozoic eon. Given a typical asteroid / short-period comet encounter speed of 25 to $28 \mathrm{~km} / \mathrm{s}$ the ejecta produced in a terrestrial cratering event can, in principle, rapidly find its way onto orbits that intercept the Moon as well those of the planets from Mercury out to Jupiter, thereby populating the solar system with material that harbours viable populations of terrestrial microbes.
\end{abstract}

Keywords: Impact Craters, Chicxulub Crater, Impact Ejecta, Lithopanspermia

\section{Introduction}

The promise of space exploration in the near-term future suggests a return of humans to the lunar surface, the development of permanent lunar bases, and the continued robotic study of Martian terrains. These opportunities openup the prospects for the discovery of terrestrial impact ejecta on other worlds $[1,2]$. Such exploration, and the prospect for the future recovery of terrestrial meteorites, offers the unprecedented opportunity to test specific aspects of lithopanspermia [3-6].

The debate concerning the exchange of material and biomass between planets and moons within the solar system, and potentially with exoplanetary systems, has a long and distinguished history [7-12]. Indeed, William Thomson (later Lord Kelvin) was to comment in his Presidential address to the British Association in 1871 that, "... we must regard it as probable in the highest degree that there are countless seed- bearing meteoric stones moving about through space..." [7]. A little over a century after Thomson's insightful address the first Martian and lunar meteorites were identified from amongst the Antarctic Search for Meteorites (ANSMET) finds [13], thereby establishing the actuality of material exchange between planets and the Moon. It has long been suggested that life on Earth may have been seeded by Martian biomass transfer [14-16] although the current debate concerning the physical detection of microbes within Martian meteorites is still highly controversial. The Mars-seeding argument for terrestrial life is essentially predicated upon the assumption that in the first billion years or so in the newly formed solar system, a wetter and warmer Mars provided a more favourable environment, than that available on Earth, for abiogenesis. In the modern era, with the solar system now being some 4.5 billion years old, the situation has very definitely changed, and presently the Earth is the only known body within the solar system to support complex life. This being said, the key mechanism that enables lithopanspermia 
to operate is still active within the solar system in the form of impact cratering. In the case of the Earth it is entirely reasonable to adopt the stance that any impact ejecta produced within the past half-billion years (and potentially over the past four billion years) will contain traces of microbial life [17-20]. The question that accordingly arises with respect to this realization is, can the microbial cargo embedded within the terrestrial ejecta survive the launch, spaceflight and landing on another solar system body? The present-day consensus appears to be yes: the microbial cargo can survive all three phases of the transfer process [5, 21-25]. Accordingly, it is asked in this paper, what is the minimum amount of terrestrial material (material, that is, highly likely to contain microbial life) that has been ejected into the solar system over the past several hundred million years. A restricted geological timescale is used since it encompasses a time-frame for which the Earth's cratering record is reasonably well known (although it is far from complete) [26-28]. The rational is to focus on these more recent impacts to obtain a lower bound upon the kilogram mass of terrestrial impact ejecta deposited into the solar system over the past $\sim 550$ million years - that is, since the time of the Cambrian explosion in biodiversity.

Herein the essential characteristics of the known terrestrial impact craters will be examined (section 2); an evaluation of the amount of material ejected from the Earth's surface, with velocities greater than Earth's escape velocity, from the known cratering record over the past 550 million years will be presented (section 3) and, in additional detail, the Chicxulub impact crater, formed $65 \mathrm{Myr}$ ago, is reviewed (section 5). A summary and discussion will be given in section 6, with conclusions being presented in section 7 .

\section{The Terrestrial Cratering Record}

The total number of terrestrial impact events is not known. This being said, confirmed impact structures with varying ages, to as old as several billions of years (Vredefort) and as young as 11 years (Carancas), have been preserved in exposed surface rocks here on Earth. In this analysis the survey is restricted to terrestrial craters larger than 5 kilometers in diameter and younger than 550 million years. The lower size limit is somewhat arbitrary and is simply set on the assumption that most craters larger than this size and within the set age limit produced on land will have been discovered. The adopted age limit of 550 million years is again somewhat arbitrary, but is based upon the assumption that most of the larger land-formed craters with ages younger than this limit will have been preserved to the present day. Certainly, craters with ages much older than 550 million years are known, but the further back the cratering record is traced so the greater the number that will have been destroyed and lost to plate tectonics processes, surface weathering, in-fill and active erosion mechanisms. The analysis, at this stage, does not include known ocean-floor or continental-shelf craters, which will account for a greater number of impacts. A total of 96 impact craters satisfy the selection sieve of being larger than 5 kilometers across and no older than 550 million years in age. Table 1 provides a summary of their recorded properties. The oldest craters identified are those of Neugrund, Estonia (age 535 Ma; diameter $=8 \mathrm{~km}$ ), and Foelsche, Australia (age > $545 \mathrm{Ma}$; diameter $=6 \mathrm{~km})$. The youngest craters are Zhamanshin, Kazakhstan $($ age $=0.9 \pm 0.1 \mathrm{Ma}$; diameter $=14 \mathrm{~km})$, and Bosumtwi, Ghana (age $=1.07 \pm 0.107 \mathrm{Ma}$; diameter $=10.5$ $\mathrm{km})$. The largest craters in the set time interval are Chicxulub, Mexico (age $=64.98 \pm 0.05 \mathrm{Ma}$; diameter $=150$ $\mathrm{km})$, Popigai, Russia (age $=35 \pm 0.2 \mathrm{Ma}$; diameter $=90 \mathrm{~km}$ ), and Manicouagan, Canada (age $=214 \pm 1 \mathrm{Ma}$; diameter $=85$ $\mathrm{km}$ ). The smallest (and some of the oldest) craters are, Gardnos, Norway (age $500 \mathrm{Ma}$; diameter $=5 \mathrm{~km}$ ), Mizarai, Lithuania $($ age $=500 \mathrm{Ma}$; diameter $=5 \mathrm{~km})$, and Gow Lake, Canada (age $<250 \mathrm{Ma}$; diameter $=5 \mathrm{~km}$ ). A few words of caution should be added at this stage: it is notoriously difficult to find both an accurate age and an estimate to the initial diameter of an impact crater [26, 27]. With this in mind, the approach adopted with respect to table 1 is entirely pragmatic, and the numbers, especially those for the diameters, are simply taken as those that have been reported in the literature, with no attempt being made to take weathering and aging effects into account.

Table 1. Known terrestrial craters with ages less than 550 million years and larger than $5 \mathrm{~km}$ in diameter. The first four columns give the crater name, the country of location and the crater latitude and longitude. Column 5 and 6 give the estimated crater age and the uncertainty in the age estimate (when known). Column 7 provides the estimated crater diameter. Column 8 indicates the surface rock strata in which the crater is found: Cry = crystalline (chiefly granitic); $S e d=$ sedimentary; Bas = basalt. Column 9 indicates the impactor composition (when known): $C=$ chondrite; $I=$ iron; $A=$ achondrite; $E=e n s t a t i t e ; ~ U=$ uralite. Data from [26, 27, 28$]$.

\begin{tabular}{|c|c|c|c|c|c|c|c|c|}
\hline Crater name & Location & Latitude & Longitude & Age (Ma) & (+/- Ma) & $\mathrm{D}(\mathrm{km})$ & Strata & Imp. \\
\hline Ames & USA & $36^{\circ} 15^{\prime} \mathrm{N}$ & $98^{\circ} 12^{\prime} \mathrm{W}$ & 470 & 30 & 16 & Cry & \\
\hline Aorounga & Chad & $16^{\circ} 6^{\prime} \mathrm{N}$ & $19^{\circ} 15^{\prime} \mathrm{E}$ & $<345$ & & 12.6 & Sed & \\
\hline Araguainha & Brazil & $16^{\circ} 47^{\prime} \mathrm{S}$ & $52^{\circ} 59^{\prime} \mathrm{W}$ & 254.7 & 2.5 & 40 & Sed & \\
\hline Avak & USA & $71^{\circ} 15.1^{\prime} \mathrm{N}$ & $156^{\circ} 27.3^{\prime} \mathrm{W}$ & 49 & 28 & 12 & Sed & \\
\hline Beyenchime-Salaatin & Russia & $71^{\circ} 0^{\prime} \mathrm{N}$ & $121^{\circ} 40^{\prime} \mathrm{E}$ & 40 & 20 & 8 & Sed & \\
\hline Bigach & Kazakhstan & $48^{\circ} 34^{\prime} \mathrm{N}$ & $82^{\circ} 1^{\prime} \mathrm{E}$ & 5 & 3 & 8 & Sed & \\
\hline Boltysh & Ukraine & $48^{\circ} 45^{\prime} \mathrm{N}$ & $32^{\circ} 10^{\prime} \mathrm{E}$ & 65.17 & 0.64 & 24 & Cry & $\mathrm{C}$ \\
\hline Calvin & USA & $41^{\circ} 50^{\prime} \mathrm{N}$ & $85^{\circ} 57^{\prime} \mathrm{W}$ & 450 & 10 & 8.5 & Sed & \\
\hline Carswell & Canada & $58^{\circ} 26^{\prime} \mathrm{N}$ & $109^{\circ} 30^{\prime} \mathrm{W}$ & 115 & 10 & 39 & Cry & \\
\hline Charlevoix & Canada & $47^{\circ} 32^{\prime} \mathrm{N}$ & $70^{\circ} 18^{\prime} \mathrm{W}$ & 342 & 15 & 54 & Sed & \\
\hline Chesapeake & USA & $37^{\circ} 17^{\prime} \mathrm{N}$ & $76^{\circ} 1^{\prime} \mathrm{W}$ & 35.3 & 0.1 & 40 & Sed & \\
\hline
\end{tabular}




\begin{tabular}{|c|c|c|c|c|c|c|c|c|}
\hline Crater name & Location & Latitude & Longitude & Age (Ma) & (+/- Мa) & $\mathrm{D}(\mathrm{km})$ & Strata & Imp. \\
\hline Chicxulub & Mexico & $21^{\circ} 20^{\prime} \mathrm{N}$ & $89^{\circ} 30^{\prime} \mathrm{W}$ & 64.98 & 0.05 & 150 & Sed & \\
\hline Chiyli & Kazakhstan & $49^{\circ} 10^{\prime} \mathrm{N}$ & $57^{\circ} 51^{\prime} \mathrm{W}$ & 46 & 7 & 5.5 & Sed & \\
\hline Chukcha & Russia & $75^{\circ} 42^{\prime} \mathrm{N}$ & $97^{\circ} 48^{\prime} \mathrm{E}$ & $<70$ & ? & 6 & Sed & \\
\hline Clearwater East & Canada & $56^{\circ} 5^{\prime} \mathrm{N}$ & $74^{\circ} 7^{\prime} \mathrm{W}$ & $460-470$ & & 26 & Sed & $\mathrm{C}$ \\
\hline Clearwater West & Canada & $56^{\circ} 13^{\prime} \mathrm{N}$ & $74^{\circ} 30^{\prime} \mathrm{W}$ & 290 & 20 & 36 & Sed & \\
\hline Cloud Creek & USA & $43^{\circ} 7^{\prime} \mathrm{N}$ & $106^{\circ} 45^{\prime} \mathrm{W}$ & 190 & 30 & 7 & Sed & \\
\hline Connolly Basin & Australia & $23^{\circ} 32^{\prime} \mathrm{S}$ & $124^{\circ} 45^{\prime} \mathrm{E}$ & $<65$ & $?$ & 9 & Sed & \\
\hline Couture & Canada & $60^{\circ} 8^{\prime} \mathrm{N}$ & $75^{\circ} 20^{\prime} \mathrm{W}$ & 430 & 25 & 8 & Cry & \\
\hline Crooked Creek & USA & $37^{\circ} 50^{\prime} \mathrm{N}$ & $91^{\circ} 23^{\prime} \mathrm{W}$ & 320 & 80 & 7 & Sed & \\
\hline Decaturville & USA & $37^{\circ} 54^{\prime} \mathrm{N}$ & $92^{\circ} 43^{\prime} \mathrm{W}$ & $<300$ & & 6 & Sed & \\
\hline Deep Bay & Canada & $56^{\circ} 24^{\prime} \mathrm{N}$ & $103^{\circ} 00^{\prime} \mathrm{W}$ & 99 & 4 & 13 & Cry & \\
\hline Dellen & Sweden & $61^{\circ} 48^{\prime} \mathrm{N}$ & $16^{\circ} 48^{\prime} \mathrm{E}$ & 89 & 2.7 & 19 & Cry & $\mathrm{C}$ \\
\hline Des Plaines & USA & $42^{\circ} 3^{\prime} \mathrm{N}$ & $87^{\circ} 52^{\prime} \mathrm{W}$ & $<280$ & & 8 & Sed & \\
\hline Eagle Butte & Canada & $49^{\circ} 42^{\prime} \mathrm{N}$ & $110^{\circ} 30^{\prime} \mathrm{W}$ & $<65$ & & 10 & Sed & \\
\hline El'gygytgyn & Russia & $67^{\circ} 30^{\prime} \mathrm{N}$ & $172^{\circ} 34^{\prime} \mathrm{E}$ & 3.58 & 0.04 & 18 & Cry & A \\
\hline Elbow & Canada & $50^{\circ} 59^{\prime} \mathrm{N}$ & $106^{\circ} 43^{\prime} \mathrm{W}$ & 395 & 25 & 8 & Sed & \\
\hline Foelsche & Australia & $16^{\circ} 40^{\prime} \mathrm{S}$ & $136^{\circ} 47^{\prime} \mathrm{E}$ & $>545$ & & 6 & Sed & \\
\hline Gardnos & Norway & $60^{\circ} 39^{\prime} \mathrm{N}$ & $9^{\circ} 0^{\prime} \mathrm{E}$ & 500 & 10 & 5 & Cry & \\
\hline Glikson & Australia & $23^{\circ} 59^{\prime} \mathrm{S}$ & $121^{\circ} 34^{\prime} \mathrm{E}$ & $<508$ & & 19 & Cry & \\
\hline Glover Bluff & USA & $43^{\circ} 58^{\prime} \mathrm{N}$ & $89^{\circ} 32^{\prime} \mathrm{W}$ & $<500$ & & 8 & Sed & \\
\hline Goat Paddock & Australia & $18^{\circ} 20^{\prime} \mathrm{S}$ & $126^{\circ} 40^{\prime} \mathrm{E}$ & $>48.6$ & & 5.1 & Sed & \\
\hline Gow & Canada & $56^{\circ} 27^{\prime} \mathrm{N}$ & $104^{\circ} 29^{\prime} \mathrm{W}$ & $<250$ & & 5 & Cry & I \\
\hline Gosses Bluff & Australia & $23^{\circ} 49^{\prime} \mathrm{S}$ & $132^{\circ} 19^{\prime} \mathrm{E}$ & 142.5 & 0.8 & 22 & Sed & \\
\hline Gweni-Fada & Chad & $17^{\circ} 25^{\prime} \mathrm{N}$ & $21^{\circ} 45^{\prime} \mathrm{E}$ & $<345$ & & 14 & Sed & \\
\hline Haughton & Canada & $75^{\circ} 22^{\prime} \mathrm{N}$ & $89^{\circ} 40^{\prime} \mathrm{W}$ & 39 & 3.9 & 23 & Sed & \\
\hline Ilyinets & Ukraine & $49^{\circ} 7^{\prime} \mathrm{N}$ & $29^{\circ} 6^{\prime} \mathrm{E}$ & 378 & 5 & 8.5 & Sed & I \\
\hline Jebel Waqf as Suwwan & Jordan & $31^{\circ} 03^{\prime} \mathrm{N}$ & $36^{\circ} 48^{\prime} \mathrm{E}$ & 46.5 & 5.8 & 5.5 & Sed & \\
\hline Kaluga & Russia & $54^{\circ} 30^{\prime} \mathrm{N}$ & $36^{\circ} 10^{\prime} \mathrm{E}$ & 380 & 5 & 15 & Sed & \\
\hline Kamensk & Russia & $48^{\circ} 21^{\prime} \mathrm{N}$ & $40^{\circ} 30^{\prime} \mathrm{E}$ & 49 & 0.2 & 25 & Sed & $\mathrm{C}$ \\
\hline Kara & Russia & $69^{\circ} 6^{\prime} \mathrm{N}$ & $64^{\circ} 9^{\prime} \mathrm{E}$ & 70.3 & 2.2 & 65 & Sed & $\mathrm{C}$ \\
\hline Kara-Kul & Tajikistan & $39^{\circ} 1^{\prime} \mathrm{N}$ & $73^{\circ} 27^{\prime} \mathrm{E}$ & $<5$ & & 52 & Sed & \\
\hline Karla & Russia & $54^{\circ} 55^{\prime} \mathrm{N}$ & $48^{\circ} 2^{\prime} \mathrm{E}$ & 5 & 1 & 10 & Sed & \\
\hline Kentland & USA & $40^{\circ} 45^{\prime} \mathrm{N}$ & $87^{\circ} 24^{\prime} \mathrm{W}$ & $<97$ & & 13 & Sed & \\
\hline Kursk & Russia & $51^{\circ} 42^{\prime} \mathrm{N}$ & $36^{\circ} 0^{\prime} \mathrm{E}$ & 250 & 80 & 6 & Sed & \\
\hline La Moinerie & Canada & $57^{\circ} 26^{\prime} \mathrm{N}$ & $66^{\circ} 37^{\prime} \mathrm{W}$ & 400 & 50 & 8 & Cry & \\
\hline Lappajärvi & Finland & $63^{\circ} 09^{\prime} \mathrm{N}$ & $23^{\circ} 42^{\prime} \mathrm{E}$ & 76.2 & 0.29 & 23 & Sed & $\mathrm{C}$ \\
\hline Lawn Hill & Australia & $18^{\circ} 40^{\prime} \mathrm{S}$ & $138^{\circ} 39^{\prime} \mathrm{E}$ & $>515$ & & 18 & Sed & \\
\hline Lockne & Sweden & $63^{\circ} 0^{\prime} \mathrm{N}$ & $14^{\circ} 49^{\prime} \mathrm{E}$ & 458 & & 7.5 & Sed & \\
\hline Logancha & Russia & $65^{\circ} 31^{\prime} \mathrm{N}$ & $95^{\circ} 56^{\prime} \mathrm{E}$ & 40 & 20 & 20 & Bas & \\
\hline Logoisk & Belarus & $54^{\circ} 12^{\prime} \mathrm{N}$ & $27^{\circ} 48^{\prime} \mathrm{E}$ & 42.3 & 1.1 & 15 & Sed & \\
\hline Manicouagan & Canada & $51^{\circ} 23^{\prime} \mathrm{N}$ & $68^{\circ} 42^{\prime} \mathrm{W}$ & 214 & 1 & 85 & Sed & \\
\hline Manson & USA & $42^{\circ} 53^{\prime} \mathrm{N}$ & $94^{\circ} 33^{\prime} \mathrm{W}$ & 73.8 & 0.3 & 35 & Sed & $\mathrm{C}$ \\
\hline Maple Creek & Canada & $49^{\circ} 35^{\prime} \mathrm{N}$ & $109^{\circ} 6^{\prime} \mathrm{W}$ & $<75$ & & 6 & Sed & \\
\hline Marquez & USA & $31^{\circ} 17^{\prime} \mathrm{N}$ & $96^{\circ} 18^{\prime} \mathrm{W}$ & 58 & 2 & 12.7 & Sed & \\
\hline Middlesboro & USA & $36^{\circ} 37^{\prime} \mathrm{N}$ & $83^{\circ} 44^{\prime} \mathrm{E}$ & $<300$ & & 6 & Sed & \\
\hline Mien & Sweden & $56^{\circ} 25^{\prime} \mathrm{N}$ & $14^{\circ} 52^{\prime} \mathrm{E}$ & 121 & 2.3 & 9 & Cry & $\mathrm{C}$ \\
\hline Mistastin & Canada & $55^{\circ} 53^{\prime} \mathrm{N}$ & $63^{\circ} 18^{\prime} \mathrm{W}$ & 36.4 & 4 & 28 & Cry & I \\
\hline Mizarai & Lithuania & $54^{\circ} 1^{\prime} \mathrm{N}$ & $23^{\circ} 54^{\prime} \mathrm{E}$ & 500 & 20 & 5 & Cry & \\
\hline Mjølnir & Norway & $73^{\circ} 48^{\prime} \mathrm{N}$ & $29^{\circ} 40^{\prime} \mathrm{E}$ & 142 & 2.6 & 40 & Sed & \\
\hline Montagnais & Canada & $42^{\circ} 53^{\prime} \mathrm{N}$ & $64^{\circ} 13^{\prime} \mathrm{W}$ & 50.5 & 0.76 & 45 & Sed & \\
\hline Morokweng & South Africa & $26^{\circ} 28^{\prime} \mathrm{S}$ & $23^{\circ} 32^{\prime} \mathrm{E}$ & 145 & 0.8 & 70 & Sed & $\mathrm{C}$ \\
\hline Neugrund & Estonia & $59^{\circ} 20^{\prime} \mathrm{N}$ & $23^{\circ} 40^{\prime} \mathrm{E}$ & $\sim 535$ & & 8 & Sed & \\
\hline Nicholson & Canada & $62^{\circ} 40^{\prime} \mathrm{N}$ & $102^{\circ} 41^{\prime} \mathrm{W}$ & $<400$ & & 12.5 & Sed & U \\
\hline Oasis & Libya & $24^{\circ} 35^{\prime} \mathrm{N}$ & $24^{\circ} 24^{\prime} \mathrm{E}$ & $<120$ & & 18 & Sed & \\
\hline Obolon' & Ukraine & $49^{\circ} 35^{\prime} \mathrm{N}$ & $32^{\circ} 55^{\prime} \mathrm{E}$ & 169 & 7 & 20 & Sed & \\
\hline Piccaninny & Australia & $17^{\circ} 32^{\prime} \mathrm{S}$ & $128^{\circ} 25^{\prime} \mathrm{E}$ & $<360$ & & 7 & Sed & \\
\hline Pilot & Canada & $60^{\circ} 17^{\prime} \mathrm{N}$ & $111^{\circ} 1^{\prime} \mathrm{E}$ & 445 & 2 & 6 & Cry & \\
\hline Popigai & Russia & $71^{\circ} 39^{\prime} \mathrm{N}$ & $111^{\circ} 11^{\prime} \mathrm{E}$ & 35.7 & 0.2 & 90 & Sed & $\mathrm{C}$ \\
\hline Presqu'île & Canada & $49^{\circ} 43^{\prime} \mathrm{N}$ & $74^{\circ} 48^{\prime} \mathrm{W}$ & $<500$ & & 24 & Bas & \\
\hline Puchezh-Katunki & Russia & $56^{\circ} 58^{\prime} \mathrm{N}$ & $43^{\circ} 43^{\prime} \mathrm{E}$ & 167 & 3 & 40 & Sed & \\
\hline Ragozinka & Russia & $58^{\circ} 44^{\prime} \mathrm{N}$ & $61^{\circ} 48^{\prime} \mathrm{W}$ & 46 & 3 & 9 & Sed & \\
\hline Red Wing & USA & $47^{\circ} 36^{\prime} \mathrm{N}$ & $103^{\circ} 33^{\prime} \mathrm{W}$ & 200 & 25 & 9 & Sed & \\
\hline Ries & Germany & $48^{\circ} 53^{\prime} \mathrm{N}$ & $10^{\circ} 37^{\prime} \mathrm{E}$ & 15.1 & 0.1 & 24 & Sed & $\mathrm{E}$ \\
\hline Rochechouart & France & $45^{\circ} 50^{\prime} \mathrm{N}$ & $0^{\circ} 56^{\prime} \mathrm{E}$ & 201 & 2 & 23 & Cry & I \\
\hline Rock Elm & USA & $44^{\circ} 43^{\prime} \mathrm{N}$ & $92^{\circ} 14^{\prime} \mathrm{W}$ & $<505$ & & 6.5 & Sed & \\
\hline Saint Martin & Canada & $51^{\circ} 46^{\prime} \mathrm{N}$ & $98^{\circ} 32^{\prime} \mathrm{W}$ & 220 & 32 & 40 & Sed & \\
\hline Serpent Mound & USA & $39^{\circ} 2^{\prime} \mathrm{N}$ & $83^{\circ} 24^{\prime} \mathrm{W}$ & $<320$ & & 8 & Sed & \\
\hline
\end{tabular}




\begin{tabular}{|c|c|c|c|c|c|c|c|c|}
\hline Crater name & Location & Latitude & Longitude & Age (Ma) & (+/- Мa) & $\mathbf{D}(\mathbf{k m})$ & Strata & Imp. \\
\hline Serra da Cangalha & Brazil & $8^{\circ} 5^{\prime} \mathrm{S}$ & $46^{\circ} 52^{\prime} \mathrm{W}$ & $<300$ & & 12 & Sed & \\
\hline Sierra Madera & USA & $30^{\circ} 36^{\prime} \mathrm{S}$ & $102^{\circ} 55^{\prime} \mathrm{W}$ & $<100$ & & 13 & Sed & \\
\hline Siljan & Sweden & $61^{\circ} 2^{\prime} \mathrm{N}$ & $14^{\circ} 52^{\prime} \mathrm{E}$ & 376.8 & 1.7 & 52 & Sed & \\
\hline Slate Islands & Canada & $48^{\circ} 40^{\prime} \mathrm{N}$ & $86^{\circ} 0^{\prime} \mathrm{W}$ & 450 & & 30 & Cry & \\
\hline Steen River & Canada & $59^{\circ} 31^{\prime} \mathrm{N}$ & $117^{\circ} 39^{\prime} \mathrm{W}$ & 91 & 7 & 25 & Sed & \\
\hline Ternovka & Ukraine & $48^{\circ} 08^{\prime} \mathrm{N}$ & $33^{\circ} 31^{\prime} \mathrm{E}$ & 280 & 10 & 11 & Cry & $\mathrm{C}$ \\
\hline Tin Bider & Algeria & $27^{\circ} 07^{\prime} \mathrm{N}$ & $5^{\circ} 7^{\prime} \mathrm{E}$ & $<70$ & & 6 & Sed & \\
\hline Upheaval Dome & USA & $38^{\circ} 26^{\prime} \mathrm{S}$ & $109^{\circ} 54^{\prime} \mathrm{W}$ & $<170$ & & 10 & Sed & \\
\hline Vargeão Dome & Brazil & $26^{\circ} 50^{\prime} \mathrm{S}$ & $52^{\circ} 07^{\prime} \mathrm{W}$ & 123 & 1.4 & 12 & Sed & \\
\hline Vista Alegre & Brazil & $25^{\circ} 57^{\prime} \mathrm{S}$ & $52^{\circ} 41^{\prime} \mathrm{W}$ & $<65$ & & 9.5 & Sed & \\
\hline Wanapitei & Canada & $46^{\circ} 45^{\prime} \mathrm{N}$ & $80^{\circ} 45^{\prime} \mathrm{W}$ & 37.2 & 1.2 & 7.5 & Sed & $\mathrm{C}$ \\
\hline Wells Creek & USA & $36^{\circ} 23^{\prime} \mathrm{N}$ & $87^{\circ} 40^{\prime} \mathrm{W}$ & 200 & 100 & 12 & Sed & \\
\hline Wetumpka & USA & $32^{\circ} 31^{\prime} \mathrm{N}$ & $86^{\circ} 10^{\prime} \mathrm{W}$ & 81 & 1.5 & 6.5 & Sed & $\mathrm{C}$ \\
\hline Woodleigh & Australia & $26^{\circ} 3^{\prime} \mathrm{S}$ & $114^{\circ} 39^{\prime} \mathrm{E}$ & 364 & 8 & 40 & Sed & \\
\hline Zhamanshin & Kazakhstan & $48^{\circ} 24^{\prime} \mathrm{N}$ & $60^{\circ} 58^{\prime} \mathrm{E}$ & 0.9 & 0.1 & 14 & Sed & $\mathrm{C}$ \\
\hline
\end{tabular}

\section{Estimation of Ejecta Mass}

The process of crater formation is highly complex and in general requires the implementation of extensive numerical techniques to follow the time evolution of an asteroid's first contact, substrate compression, relaxation and eventual crater excavation [29]. Remarkably, however, a number of simplified, yet accurate, analytic formulae have been derived to account for both crater and ejecta characteristics [3, 3032]. With reference to figure 1 , the diameter of the transient crater $\mathrm{D}_{\mathrm{t}}$ produced by an impactor of radius a, density $\rho_{\mathrm{imp}}$ and impact velocity $V_{\text {imp }}$ is accordingly given by the relation:

$$
\mathrm{D}_{\mathrm{t}}=1.075\left(\frac{\rho_{\text {imp }}}{\rho_{\mathrm{t} \text { arg et }}}\right)^{1 / 3} \mathrm{a}^{0.78} \mathrm{~V}_{\mathrm{imp}}^{0.44}
$$

Where $\rho_{\text {target }}$ is the density of the impacted substrate, and where a most probable impact angle of $\theta=45$ degrees is assumed. The final crater size $D_{f}$ is related to that of the transient crater by the relationship: $\mathrm{D}_{\mathrm{f}}=1.25 \mathrm{D}_{\mathrm{t}}$.

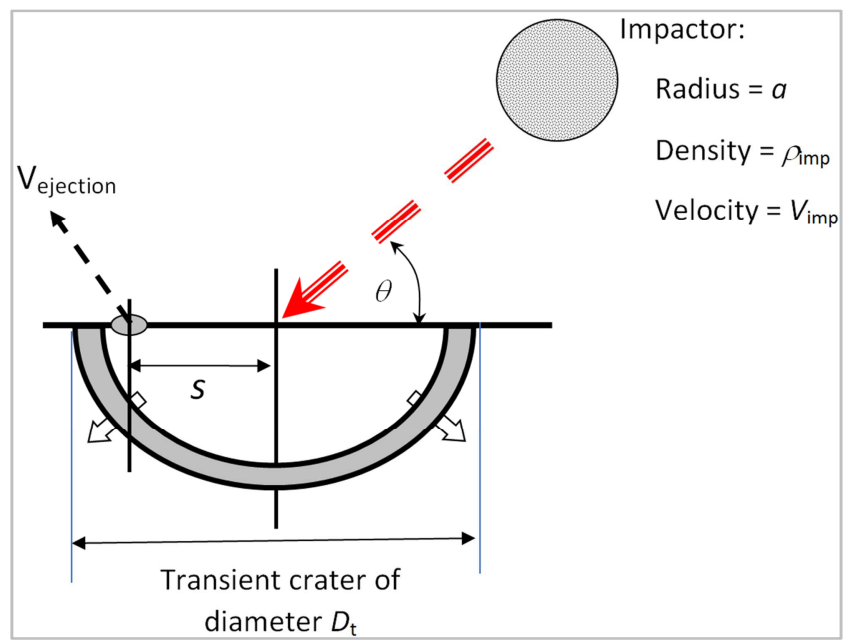

Figure 1. Diagram illustrating the input parameters used in determining equations (1) through (5). The impactor is assumed to be spherical, and the impact angle is taken as $\theta=45 \mathrm{deg}$.

Furthermore, the material ejection velocity depends upon the distance from the impact contact point and the velocity of the impactor according to the relationship [3]:

$$
\mathrm{V}_{\text {ejection }}=\mathrm{V}_{\text {imp }}\left(\frac{\mathrm{a}}{\mathrm{r}}\right)^{2.87}>\mathrm{V}_{\text {escape }}=\sqrt{\frac{2 \mathrm{GM}_{\text {Earth }}}{\mathrm{R}_{\text {Earth }}}}
$$

Where $r=\left(s^{2}+a^{2}\right)^{1 / 2}$ and $V_{\text {escape }}$ is the escape velocity - in the case of the Earth, $V_{\text {escape }}=11.2 \mathrm{~km} / \mathrm{s}$. The amount of material ejected, $m_{\text {ejected}}$, with a speed greater than the escape velocity is further given by the expression [3]:

$$
\mathrm{f}=\frac{\mathrm{m}_{\text {ejected }}}{\mathrm{m}_{\text {impactor }}}=0.75 \frac{\mathrm{P}_{\mathrm{m}}}{\rho_{\text {targ et }} \mathrm{c} \mathrm{V}_{\text {imp }}}\left[\left(\frac{\mathrm{V}_{\text {imp }}}{2 \mathrm{~V}_{\text {escape }}}\right)^{5 / 3}-1\right]
$$

where $\mathrm{m}_{\text {impactor }}$ is the mass of the impactor, $\mathrm{P}_{\mathrm{m}}$ is the maximum pressure that the ejecta is subjected to, and $\mathrm{c}$ is the speed of sound in the substrate material. The impactor mass is expressed in terms of its parameterized radius and density:

$$
\mathrm{m}_{\text {impactor }}=\frac{4 \pi}{3} \mathrm{a}^{3} \rho_{\mathrm{imp}}
$$

The characteristic boulder size $\mathrm{D}_{\mathrm{B}}$ within the ejecta spray is expressed according to the equation:

$$
\mathrm{D}_{\mathrm{B}}=\frac{2 \mathrm{~T} \mathrm{a}}{\rho_{\text {target }} \mathrm{V}_{\text {eject }}^{2 / 3} \mathrm{~V}_{\text {imp }}^{4 / 3}}
$$

Where $\mathrm{T}$ is the tensile strength of the substrate rock. For the purposes of this study, equations (1) through (5) provide a complete profile of the impactor, the final impact crater diameter, as well as the velocity and size characteristics of the ejected material. The parameter space that requires specification in order to go from measured impact crater size $D_{f}$ to $m_{\text {ejecta }}$ and $D_{B}$ is that for the density of the impactor and surface substrate, the impact velocity, the maximum shock pressure that the ejecta material is to be subjected to, and the tensile strength of the target substrate material. Table 2 provides an overview of the adopted values for the density terms. The maximum shock pressure is taken as $1 \mathrm{GPa}$, the tensile strength of target material is assumed to be $100 \mathrm{MPa}$, and the sound speed in the substrate material is fixed at a characteristic value of $\mathrm{c}=4000 \mathrm{~m} / \mathrm{s}$. 
Table 2. The density values adopted in this analysis of the impact cratering process. Meteorite density data from [33] and references therein.

\begin{tabular}{ll}
\hline Material & Density $\left(\mathbf{k g} / \mathbf{m}^{3}\right)$ \\
\hline Uralite & 3050 \\
Achondrite & 3200 \\
LL Chondrite & 3210 \\
Ordinary Chondrite & 3400 \\
Enstatite & 3720 \\
Iron & 7900 \\
Cometary nucleus - ice & 1000 \\
Sedimentary substrate & 2500 \\
Crystalline substrate & 2750 \\
Basalt substrate & 3000 \\
\hline
\end{tabular}

With the above parameter terms specified it is possible to move from the measure of the impact crater diameter to a determination of the asteroid size and the fraction $f$ of the impactor mass that was ejected, from the newly formed crater, with a speed greater than the Earth's escape velocity. The only remaining parameter to quantify is that of the impactor's velocity. The characteristic speed for Earth impacting objects will vary from $20-25 \mathrm{~km} / \mathrm{s}$ for typical nearEarth asteroids and short period comets, up to $50-60 \mathrm{~km} / \mathrm{s}$ for long-period comets [34, 35].

The total amount of material ejected from the Earth, with a speed greater than $V_{\text {escape }}$, in response to the formation of the various craters listed in table 1 can now be evaluated. The procedure applied is to first adopt a density for the impactor. If meteorites have been found (or impactor composition inferred) at a specific location then an appropriate chondritic or iron density is adopted. If there is no information about the impactor available then it is assumed to have an ordinary chondrite composition. The density of the impacted substrate is based upon the terrain within which the crater is found (with a density taken from table 2). When the impactor velocity is taken to be $25 \mathrm{~km} / \mathrm{s}$, characteristic of a typical NEA population of impactors [34], a total of $8.23 \times 10^{12} \mathrm{~kg}$ of material is ejected from the Earth (that is having $\mathrm{V}_{\text {eject }}>$ $\mathrm{V}_{\text {escape }}$ ) in the production of the known craters listed in table 1. If the characteristic impactor velocity is pushed to $30 \mathrm{~km} / \mathrm{s}$, then a total of $1.56 \times 10^{13} \mathrm{~kg}$ of material is ejected from the Earth in response to the formation of the craters listed in table 1. During the 550-million-year time span under consideration the Chicxulub crater contributes some $67 \%$ of the total amount of matter ejected from the Earth - this being the case simply because it is the largest (extant) crater to have formed in the chosen time interval.

\section{Fate of the Ejecta}

After impact has occurred, the ejecta with $\mathrm{V}_{\text {eject }}<\mathrm{V}_{\text {escape }}$ will soon fall back to Earth, forming an ejecta blanket. That ejecta with $\mathrm{V}_{\text {eject }}>\mathrm{V}_{\text {escape }}$ will find itself no longer bound to the Earth, and can, in principle, begin a voyage to another planet or moon, or to the Sun. Of specific interest at this stage, however, is the determination of the conditions under which ejecta might find its way to the Moon's orbit along with the orbits of Mars and Venus. Upon being launched from the crater site and surviving passage through Earth's atmosphere, the ejecta will initially adopt a heliocentric orbit with a perihelion distance close to that of Earth's orbit (that is of radius $1 \mathrm{AU}=1.495 \times 10^{8} \mathrm{~km}$ ). The actual values of the perihelion and aphelion distances, however, will depend upon the difference between the ejection velocity and the Earth's escape velocity. That is, the velocity of the ejected material in its new orbit about the Sun will be $V_{\text {esun }}=V_{E} \pm V_{\infty}$, where $V_{E}$ $=29.3 \mathrm{~km} / \mathrm{s}$ is the Earth's orbital velocity, and $\mathrm{V}_{\infty}=\left(\mathrm{V}_{\text {eject }}^{2}-\right.$ $\left.\mathrm{V}_{\text {escape }}^{2}\right)^{1 / 2}$. The \pm term in the expression for $\mathrm{V}_{\text {esun }}$ comes about since the impact event can take place on either the leading of trailing hemisphere of the Earth as it orbits about the Sun. The orbital semi-major axis $a_{p}$ and eccentricity e of the orbit adopted by an ejected particle are calculated as:

$$
\frac{1}{a_{p}}=\left(\frac{2}{r_{E}}-\frac{V_{\text {esun }}^{2}}{G_{\text {sun }}}\right)
$$

and

$$
\mathrm{e}=\sqrt{\left(1-\frac{\mathrm{h}^{2}}{\mathrm{GM}_{\text {sun }} \mathrm{ap}_{\mathrm{p}}}\right)}
$$

Where $M_{\text {sun }}$ is the mass of the Sun, $G$ is the gravitational constant, $r_{E}$ is the Earth's orbital radius and $h$ is the ejecta's angular momentum: $h=r_{E} V_{\text {esun. }}$. Once the orbital semi-major axis and the eccentricity are known then the perihelion distance $\mathrm{q}$ and the aphelion distance $\mathrm{Q}$ can be determined, with $\mathrm{q}=\mathrm{a}_{\mathrm{p}}(1-\mathrm{e})$ and $\mathrm{Q}=\mathrm{a}_{\mathrm{p}}(1+\mathrm{e})$.

The distribution function for the total mass ejected $\mathrm{m}_{\text {eject }}$ (recall equation 3 ) that leaves the Earth in the velocity range $\mathrm{V}_{\text {escape }}<\mathrm{V}<\mathrm{V}_{\text {eject }}$ has been estimated to vary as $[6,11]$ :

$$
\mathrm{F}\left(\mathrm{V}_{\text {escape }}<\mathrm{V}<\mathrm{V}_{\text {eject }}\right)=\frac{1-\left(\mathrm{V}_{\text {eject }} / \mathrm{V}_{\text {escape }}\right)^{-5 / 3}}{1-\left(\mathrm{V}_{\text {eject }} / 2 \mathrm{~V}_{\text {imp }}\right)^{-5 / 3}}
$$

The distribution function given in equation (8) is unity when $\mathrm{V}_{\text {eject }}=1 / 2 \mathrm{~V}_{\text {imp }}$, and this sets an upper limit to the ejection speed. Figure 2 shows the variation of $\mathrm{q}$ and $\mathrm{Q}$ for variously assumed impact velocities in the range $20<V_{\text {imp }}$ $(\mathrm{km} / \mathrm{s})<40$, under the assumption that $\mathrm{V}_{\text {eject }}=1 / 2 \mathrm{~V}_{\text {imp }}$.

As expected the greater the ejection velocity so the greater the range, between perihelion and aphelion over which an ejected particle can move. Should another body, the Moon, Venus or Mars traverse the zone in which the ejected particle moves, so a possible capture event might take place. In the case of the Moon capture events will entail a direct surface impact; for Mars, the material must first undergo atmospheric deceleration before it reaches the ground; for Venus intercepts, the material must also undergo atmospheric deceleration. At this stage the ejecta capture conditions are not followed, although they will be described in a future paper. For ejecta to potentially encounter the Moon, Mars or Venus the following conditions on $\mathrm{q}$ and Q must apply: Moon capture requires $\mathrm{q}<0.9976 \mathrm{AU}$ and $\mathrm{Q}>1.0024 \mathrm{AU}$. For Venus intercept, $\mathrm{q}<0.7233 \mathrm{AU}$, and for Mars intercept, $\mathrm{Q}>$ 1.5237 AU. With these conditions in place, for ejecta to reach the orbits of Venus and/or Mars the impact velocity must be greater than $23 \mathrm{~km} / \mathrm{s}$. To reach the orbit of Mercury, an impact velocity greater than $27 \mathrm{~km} / \mathrm{s}$ will be needed. In order 
for ejecta to reach Jupiter and its attendant moons the impact velocity will need to exceed some $28 \mathrm{~km} / \mathrm{s}$. All these impact velocities fall within the characteristic range expected for most asteroids and short period comets $[34,35]$. In principle, collisions between the Earth and long period comets, which have impact velocities of order $60 \mathrm{~km} / \mathrm{s}$, might produce ejecta capable of intercepting the orbit of Saturn and its attendant moons. In the case of terrestrial material being transferred to Jupiter and Saturn, the question of terrestrial microbes potentially contaminating the surfaces of Europa, Enceladus and Titan becomes particularly interesting since these locations may well support sanctuaries capable of supporting life beyond the Earth's biosphere [36, 37]. In principle, material with the appropriate ejection velocities required to reach the Moon and/or one of the planets may do so very quickly, indeed arriving at its potential target on a timescale of weeks to months, even days with respect to the Moon. It is more likely, however, that any ejected material will have to spend much longer time intervals, hundreds to thousands of years, in space prior to impact, and under these circumstances gravitational perturbation calculations will need to be employed $[6,11,38]$.

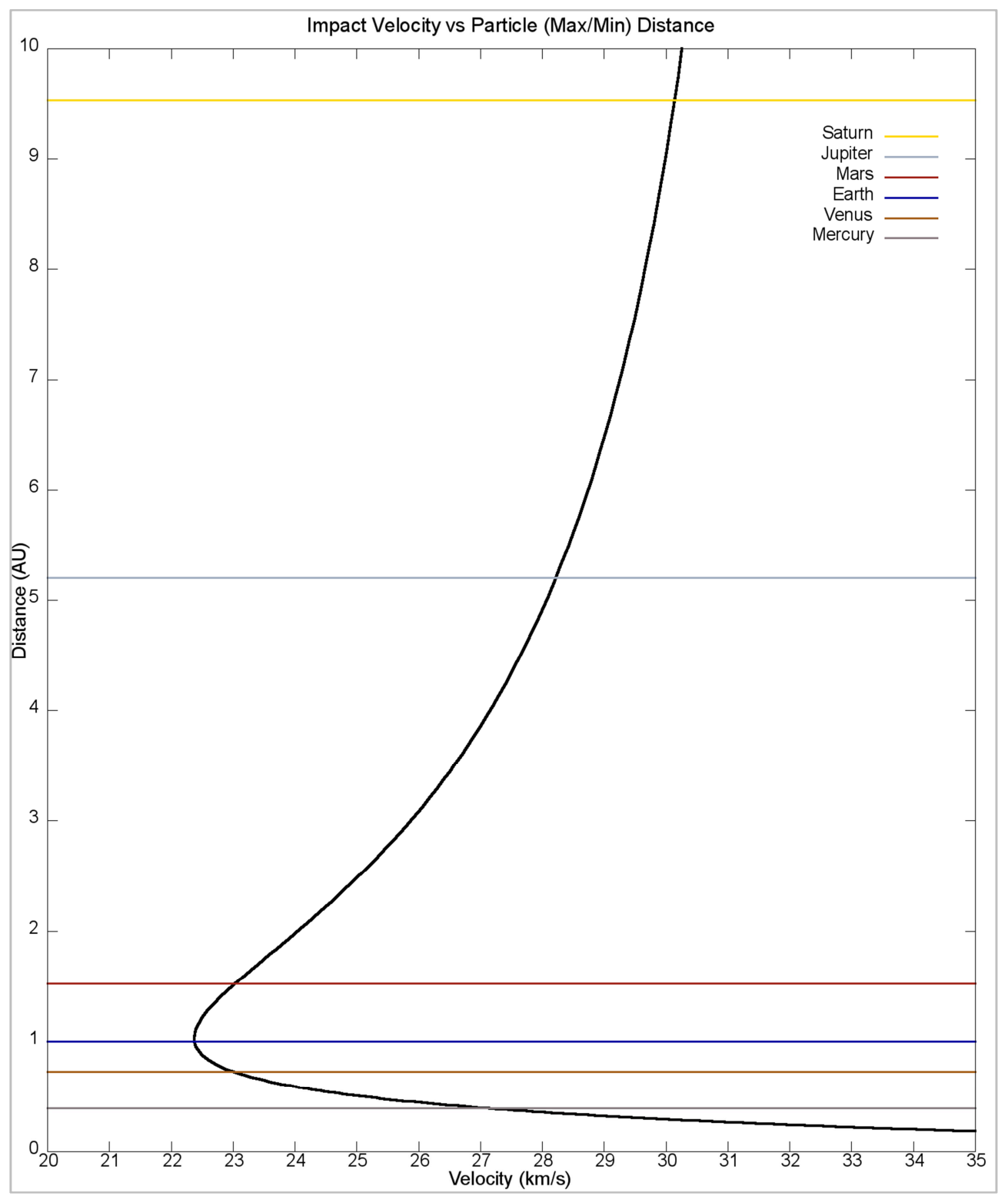

Figure 2. Potential initial range of perihelion and aphelion distance for the maximum ejection speed $V_{\text {eject }}$ debris plotted against impactor velocity $V_{\text {imp. }}$. The horizontal lines correspond to the mean orbital radii of Mercury, Venus, Earth, Mars, Jupiter and Saturn.

\section{Case Study of the Chicxulub Impact}

The Chicxulub crater, with a diameter of some $150 \mathrm{~km}$ and an age of 65-million-years, is the largest impact structure to have formed within the 550 Myr timespan that has been adopted for consideration. Given an impactor velocity of 25 $\mathrm{km} / \mathrm{s}$ of order $5.5 \times 10^{12} \mathrm{~kg}$ of material may have been ejected from the Earth during the formation of this one crater. The characteristic mass and diameter of the Chicxulub impactor inferred from the reverse-engineered approach (via 
equations, 1,3 and 4) is $9.0 \times 10^{15} \mathrm{~kg}$, and $17.2 \mathrm{~km}$, respectively. The characteristic size of the boulders ejected from the Chicxulub crater (as deduced from equation 5) is 1.8 meters across and the characteristic boulder mass is 8.0 tonnes - such a boulder could, in principle, contain many millions of microbes.

Since its initial identification in the late 1970s the Chicxulub crater and its associated debris blanket has been intensively studied [26, 39-43]. Indeed, interest is focused upon this particular crater since its deduced formation age of $65 \mathrm{Myr}$ coincides with that of the mass extinction associated with the Cretaceous / Paleogene (K-Pg) boundary. While much has been written, and much no doubt remains to be written about the Chicxulub impact crater, here it is used to explore the consequences and variations of the parameter space that applies to equations (1) through (8).

It is not known whether the Chicxulub crater was produced by an asteroid or a cometary nucleus impact. Indeed, the energy required to excavate a crater as large as Chicxulub dictates the complete vaporization of the impactor. This being said, the distinct global iridium anomaly associated with the K-Pg boundary provides a potential constraint on the impactor's size $[40,44]$. The anomalous iridium peak in the transition sediments located between the end-Cretaceous and beginning Paleogene lithologies was first noted by Alvarez et al. [40] and its existence was used to implicate an extraterrestrial trigger for the mass-extinction associated with the K-Pg boundary. In principle, the iridium abundance in the transitionary layer can be used to constrain the size of the Chicxulub impactor, but in practice this is a far from simple exercise. Alvarez et al. [40] estimated that the global anomaly amounted to the deposition of some $\mathrm{s}=8 \mathrm{ng} / \mathrm{cm}^{2}$ of iridium over the Earth's surface - amounting to a total deposition of $\mathrm{M}(\mathrm{Ir})=\mathrm{s} \mathrm{A}_{\text {Earth }}=4.1 \times 10^{7} \mathrm{~kg}$ (where the Earth's surface area is taken to be $\left.A_{\text {Earth }}=5.101 \times 10^{14} \mathrm{~m}^{2}\right)$. Analysis of carbonaceous chondrite meteorites indicates a solar system mass fraction of $2 \times 10^{-7}$ grams per gram of material for iridium (given the siderophile nature of iridium its abundance at the Earth's surface is generally of order $5 \times 10^{-9}$ grams per gram). By assuming that the iridium in the K-Pg boundary layer was once contained within the impactor, then an impactor mass of at least $2 \times 10^{14}$ kilograms is implied by the observations. More recent estimates than that given by Alvarez et al., for the surface density of iridium at the K-Pg boundary suggest a mean global fluence of between 30 to $55 \mathrm{ng} / \mathrm{cm}^{2}$ - although the fluence measurement can vary from between $\sim 10$ and $\sim 1000 \mathrm{ng} / \mathrm{cm}^{2}$ from one location to another. Indeed, there are numerous consistency issues with respect to the iridium deposition that have as yet to be fully resolved [44-46]. Assuming an average iridium fluence of some $42.5 \mathrm{ng} / \mathrm{g}$ then an impactor of mass of order $10^{15}$ kilograms is implicated in the production of the Chicxulub crater. There is accordingly at least a factor of 45 uncertainty in the mass of the Chicxulub impactor on the basis of the available global iridium fluence recorded at the K-Pg boundary and the calculations based upon equations 1 , 3 and 4 . In deriving a size for the impactor on the basis of its estimated mass, adjustments must first be made for the unknown (and probably unknowable) properties of the impactor. Such corrections relate to uncertainties in the impactor density, porosity and the refractory dust to ice mass fraction if the impactor was a cometary nucleus. Table 3 summarizes the range in possible impactor sizes for various characteristic density estimates, likely porosity values $\mathrm{P}$ and ice to refractory element ratios. In the calculations leading to table 3 , the porosity is used to determine the bulk density through the relation: $\mathrm{P}=1-\rho_{\text {bulk }} / \rho_{\text {material, }}$ where $\rho_{\text {material }}$ is the assumed material density (given in column 2 ), and the diameter is determined as Dia $=2\left(3 \mathrm{~m} / 4 \pi \rho_{\text {bulk }}\right)^{1 / 3}$. In the case of the cometary nucleus calculations, the iridium is assumed to be entirely contained within the refractory dust component, while the porosity is restricted to the ice component of the nucleus.

Table 3. Size estimates for the Chicxulub impactor according to adopted mass, density, porosity and dust to ice ratio in the case of cometary nuclei.

\begin{tabular}{|c|c|c|c|c|}
\hline Impactor & Density $\mathrm{kg} / \mathrm{m}^{3}$ & Dia. $(\mathrm{km}) \mathrm{P}=0$ & Dia. $(\mathrm{km}) \mathrm{P}=30$ & Dia. (km) $P=60$ \\
\hline \multirow[t]{3}{*}{ Asteroid: $\mathrm{m}=10^{14} \mathrm{~kg}$} & 1500 & 5.03 & 5.67 & 6.83 \\
\hline & 3000 & 3.99 & 4.50 & 5.42 \\
\hline & 8000 & 2.88 & 3.24 & 3.91 \\
\hline \multirow[t]{3}{*}{ Asteroid: $\mathrm{m}=10^{15} \mathrm{~kg}$} & 1500 & 10.84 & 12.21 & 14.71 \\
\hline & 3000 & 8.60 & 9.69 & 11.68 \\
\hline & 8000 & 6.20 & 6.99 & 8.42 \\
\hline Comet: $\mathrm{m}=10^{14} \mathrm{~kg}$ dust $/ \mathrm{ice} \equiv 1: 1$ & $\begin{array}{l}\text { Ice: } 1000 \\
\text { Dust: } 3500\end{array}$ & 6.26 & 6.89 & 8.10 \\
\hline Comet: $\mathrm{m}=10^{15} \mathrm{~kg}$ dust $/$ ice $\equiv 1: 1$ & $\begin{array}{l}\text { Ice: } 1000 \\
\text { Dust: } 3500\end{array}$ & 13.49 & 14.85 & 17.46 \\
\hline Comet: $\mathrm{m}=10^{14} \mathrm{~kg}$ dust $/$ ice $\equiv 2: 1$ & $\begin{array}{l}\text { Ice: } 1000 \\
\text { Dust: } 3500\end{array}$ & 5.31 & 5.76 & 6.64 \\
\hline Comet: $\mathrm{m}=10^{15} \mathrm{~kg}$ dust $/ \mathrm{ice} \equiv 2: 1$ & $\begin{array}{l}\text { Ice: } 1000 \\
\text { Dust: } 3500\end{array}$ & 11.45 & 12.41 & 14.31 \\
\hline
\end{tabular}

Table 3 reveals that upon the basis of the global iridium anomaly at the K-Pg boundary, the impactor responsible for producing the Chicxulub crater can range in size from about 3 to $15 \mathrm{~km}$ across if it chanced to be an asteroid, and from about 5 to $18 \mathrm{~km}$ across if it was alternatively a cometary nucleus. Equation (1) indicates that an asteroid having a carbonaceous chondrite composition, a porosity of $30 \%$ and a mass $10^{15} \mathrm{~kg}$, and an impact velocity of $25 \mathrm{~km} / \mathrm{s}$ will produce a crater of dimeter $\sim 88 \mathrm{~km}$. A cometary nucleus of mass $10^{15}$ $\mathrm{kg}$, with a porosity of $30 \%$ and a dust to ice ratio of $1: 1$, will produce a crater with a diameter of $\sim 75 \mathrm{~km}$ if the impact velocity is $25 \mathrm{~km} / \mathrm{s}$ - or a crater of diameter $\sim 110 \mathrm{~km}$ if the 
impact velocity is $60 \mathrm{~km} / \mathrm{s}$ (characteristic of that of a longperiod comet). In each case, therefore, according to the crater-sizing relationship in equation (1), the deduced crater sizes, for the impactor characteristics derived from the global iridium anomaly calculations, are about $70 \%$ of the required size for the Chicxulub crater (with $\mathrm{D}_{\mathrm{f}}=150 \mathrm{~km}$ ), suggestive that they provide an underestimate to the impactor size rather than an upper limit.

In order to produce a crater of the correct size for the Chicxulub structure, equations 1,3 , and 4 indicates an impactor mass of some $9 \times 10^{15} \mathrm{~kg}$ and a diameter of $17.2 \mathrm{~km}$ when the impact velocity is $25 \mathrm{~km} / \mathrm{s}$ (characteristic of that expected from an NEA impact). A chondritic impactor with the latter mass will contain of order $1.8 \times 10^{9} \mathrm{~kg}$ of iridium, and if this material was evenly spread over the Earth's surface an iridium anomaly of some $353 \mathrm{ng} / \mathrm{cm}^{2}$ would result. Given the uncertainties and extreme difficulty in determining the actual global iridium anomaly value at the $\mathrm{K}-\mathrm{Pg}$ boundary, and the entirely un-known properties and speed of the actual impactor, the results deduced in the above discussion are in surprisingly good agreement (with characteristic numbers typically differing by only a factor of a few, and encouragingly by no more than an order of magnitude), although it is clear that much future work will be required in order to develop a more precise picture of events pertaining to the formation of the Chicxulub crater.

\section{Discussion}

Using the list of known terrestrial impact craters with sizes larger than $5 \mathrm{~km}$ across and ages less than 550 million years, it is estimated that at least $10^{13} \mathrm{~kg}$ of terrestrial material has been ejected into the solar system as a result of their formation - this amount of material is equivalent to that contained within a $2 \mathrm{~km}$ diameter S-type asteroid. Taking a characteristic size of a few meters across (recall equation 5) the amount of material ejected from Earth amounts to some one billion, terrestrial-life-infused, boulders. This material has the potential for impacting upon the Moon, Mars and/or Venus (given an impact velocity of $25 \mathrm{~km} / \mathrm{s}$ ), and potentially Jupiter and the Jovian moons if the impact velocity exceeds $27 \mathrm{~km} / \mathrm{s}$. Of the material ejected into the solar system, it is found that some $67 \%$ is derived from the Chicxulub impact which formed 65-million years ago. There is a certain synergy of opposites in this latter event since the mass extinction that took place at the K-Pg boundary (when the Chicxulub crater formed) is seemingly counterposed by the dramatic bacterial seeding of interplanetary space by the ejected debris [43].

Using the summary data provided by Bland and Artemieva [47] the flux of impactors larger than $10^{13} \mathrm{~kg}$ (corresponding to objects capable of producing craters larger than $5 \mathrm{~km}$ cross) is $10^{-6}$ per year across the globe. This implies some 840 craters larger than $5 \mathrm{~km}$ should have formed over the time span of 550 million years being considered. On average it is expected that only $29 \%$ of these impactors will hit rocks capable of preserving a surface (that is non-oceanic) crater, and accordingly it is expected that some 244 craters larger than $5 \mathrm{~km}$ across should have formed in the past 550 million years. The known crater count is some 2.5 times smaller than expected, and this most probably reflects the loss of smaller craters from the terrestrial record by geological processes of one kind or another (e.g., burial or erosion). Impactors in the mass range of $10^{16} \mathrm{~kg}$ and larger (i.e., those capable of producing a Chicxulub sized crater) are much less common and have a global impact probability of about $10^{-8}$ per year [47]. Accordingly, over the time interval of interest, some 5 such impactors should have encountered the Earth and 1 or 2 of these might be expect to hit land strata rather than open ocean. Some evidence for past large impactor events is available through the detection of stratigraphic microspherule layers [48, 49]. These include the Australasian microtektite layer estimated to be some 0.8 million years old, the Ivory Coast microtektite layer estimated to be some 1.1 million years old, along with the North American microtektite layer and the Chesapeake Bay structure [50], both of which are thought to be some 35 million years old. Additional evidence for a microtektite layer, associated with a large impact and a global carbon-cycle perturbation at the Paleocene-Eocene boundary (some 56 million years ago) has additional been described in the literature [51]. The un-documented craters associated with these latter events no-doubt added material to the interplanetary stockpile of terrestrial meteoroids, and could certainly increase the total amount of matter ejected, as deduced from the known craters (table 1), by perhaps an order of magnitude to $\sim 10^{14} \mathrm{~kg}$.

The dynamical evolution associated with the debris ejected in the formation of the craters listed in table 1 has not been directly followed, but it is clear than some of it, most likely a very small percentage though, will be accreted by either the Moon, Mars or Venus [6, 38]. In the case of the Moon and Mars it is entirely possible that some of the terrestrial ejecta will have been accreted with only little alteration to the original ejecta body $[52,53]$. In the case of Venus, however, its extensive atmosphere will dictate the near complete ablation of any impacting debris boulders. This latter condition may not, however, be the end of the story for any transported terrestrial microbes since, although the ground conditions on Venus are not supportive of life, there are regions within the atmosphere in which the temperature and environment (i.e., containing water vapor) are such that they could comfortably support microbial / extremophile colonies $[54,55]$. In the case of Mars there are reasons to feel relatively confident that microbial life has in the past, and may even do so in the present, existed in the near and subsurface strata of the planet [16, 56-58], and there is every hope that affirmative evidence for this possibility will be found in the near-term future through the Mars robotic exploration programs being supported by both ESA and NASA. Even the Moon, commonly assumed to be a sterile and hostile-to-life environment, may have intermittently supported substantial atmospheres [2, 52, 53] and even harboured temporary life-supporting environments. Again, evidence for this past accretion of terrestrial material and the 
possible existence of localized (but now extinct) microbial colonies may be found in the near-term future through new initiatives to explore the lunar surface.

\section{Conclusions}

It has been found that at least $10^{13} \mathrm{~kg}$ of terrestrial, potentially microbe-bearing, material has been ejected into the inner solar system since the onset of the Phanerozoic eon. This estimate is based upon the known characteristics of terrestrial impact craters with diameters larger than $5 \mathrm{~km}$ and ages less than 550 million years. The largest impact to occur in the timespan of interest is that of the Chicxulub crater, dating from 65 million years before present, and this one event is responsible for generating some $67 \%$ of the total amount of terrestrial matter ejected into interplanetary space since the onset of the Cambrian period.

\section{References}

[1] J. W. Asley et al. 2008. The scientific rationale for studying meteorites found on other worlds. White paper submitted to the 2013-2022 Planetary Science Decadal Survey Committee.

[2] A. Crawford et al. 2008. On the survivability and detectability of terrestrial meteorites on the Moon. Astrobiology, 8, 241252.

[3] H. J. Melosh. 1988. The rocky road to panspermia. Nature, $332,687-688$

[4] H. J. Melosh. 2003. Exchange of meteorites (and life?) between stellar systems. Astrobiology, 3, 207-215.

[5] D. Sloan, R. A. Batista, and A. Loeb. 2017. The resilience of life to astrophysical events. Scientific Reports, 7: 5419.

[6] M. Reys-Ruiz et al. 2012. Dynamics of escaping Earth ejecta and their collision probability with different solar system bodies. Icarus, 220, 777-786.

[7] W. Thomson. 1871. Inaugural address of the President. The Chemical News and Journal of Physical Science, 23, 49-56.

[8] S. Arrhenius 1908. Worlds in the Making: The Evolution of the Universe. New York, Harper \& Row.

[9] F. H. C. Crick, and L. E. Orgel. 1973. Directed panspermia. Icarus 19, 341-346.

[10] M. N. Mautner. 1995. Directed panspermia. 2. Technical advances toward seeding other solar systems and the foundation of panbiotic ethics. Journal of the British Interplanetary Society, 48, 435-440.

[11] B. Gladman et al. 2005. Impact seeding and reseeding in the inner solar system. Astrobiology, 5, 483-496.

[12] M. Hollinger, 2016. Life from elsewhere- early history of the maverick theory of panspermia. Sudhoffs Archiv, 100, 188205.

[13] W. A. Cassidy. 2003. Meteorites, Ice, and Antarctica. Cambridge University Press, UK.

[14] L. E. Wells, J. C. Armstrong and G. Gonzales. 2003.
Reseeding of early Earth by impacts of returning ejecta during the late heavy bombardment. Icarus, 162, 38-46.

[15] D. Stoffler et al. 2007. Experimental evidence for the potential impact ejection of viable microorganisms from Mars and Mars-like planets. Icarus, 186, 585-588.

[16] A. Pavlov et al. 2006. Was Earth ever infected by Martian biota? Clues from radioresistant bacteria. Astrobiology, 6, 911-918.

[17] H. Fumes et al. 2004. Early life recorded in Archean pillow lava. Science, 304, 578-581.

[18] E. A. Bell, P. Boehnke, T. M. Harrison, and W. L. Mao. 2015. Potentially biogenic carbon preserved in a 4.1 billion-year-old zircon. Proceedings of the National Academy of Sciences, DOI:10.1073/pnas.1517557112.

[19] J. W. Schopf et al. 2017. SIMS analysis of the oldest known assemblage of microfossils document their taxon-correlated carbon isotope compositions. Proceedings of the National Academy of Sciences, DOI:10.1073/pnas.1718063115.

[20] M. S. Dodd et al. 2017. Evidence for early life in Earth's oldest hydrothermal vent precipitates. Nature, 543, 60-64.

[21] A. Brack et al. 2002. Do meteoroids of sedimentary origin survive terrestrial atmospheric entry? The ESA artificial meteorite experiment STONE. Planetary and Space Science, 50, 763-772.

[22] W. L. Nicholson et al. 2006. Bacterial spores survive hypervelocity launch by spallation: implications for lithopanspermia. Lunar and Planetary Science XXXVII, 1808.pdf.

[23] G. Horneck et al. 2008. Microbial rock inhabitants survive hypervelocity impacts on Mars-like host planets: first phase of lithopanspermia experimentally tested. Astrobiology, 8, 17-44.

[24] R. del la Torre et al. 2010. Survival of lichens and bacteria exposed to outer space conditions : results of the lithopanspermia experiments. Icarus, 208, 735-748.

[25] R. Hazael et al. 2017. Bacterial survival following shock compression in the GigaPascal range. Icarus, 293, 1-7.

[26] R. A. F. Grieve. 1991. Terrestrial impact: the record in the rocks. Meteoritics, 26, 175-194.

[27] C. A. L. Bailer-Jones. 2011. Baysian time series analysis of terrestrial impact cratering. Monthly Notices of the Royal Astronomical Society, 416, 1163-1180.

[28] Earth Impact Database: http://www.passc.net/EarthImpactDatabase/.

[29] H. J. Melosh. 1989. Impact cratering - a geological process. Oxford University Press, Oxford.

[30] J. C. Armstrong, L. E. Wells, and G. Gonzalez.2002. Rummaging through Earth's attic for remains of ancient life. Icarus, 160, $183-196$.

[31] W. M. Napier. 2004. A mechanism for interstellar panspermia. Monthly Notices of the Royal Astronomical Society, 348, 4651 .

[32] G. S. Collins et al. 2005. Earth impact effects program. Meteoritics and Space Science, 40, 817-840. 
[33] Meteorite or meteorwrong? density \& specific gravity. $\mathrm{http}: / /$ meteorites.wustl.edu/id/density.htm.

[34] C. R. Chapman and D. Morrison. 1994. Impacts on the Earth by asteroids and comets: assessing the hazard. Nature, 367, 33-40.

[35] S. V. Jeffers, S. P. Manley, M. E. Bailey, and D. J. Asher. 2001. Near-Earth object velocity distributions and consequences for the Chicxulub impactor. Monthly Notices of the Royal Astronomical Society, 327, 126-132.

[36] B. Gladman, et al. 2006. Meteoroid transfer to Europa and Titan. Lunar and Planetary Science XXXVII, 2165.pdf.

[37] C. Sagan and E. E. Salpeter. 1976. Particles, environments and possible ecologies in the Jovian atmosphere. The Astrophysical Journal Supplement Series, 32, 737-755.

[38] R. J. Worth, S. Sigurdsson, and C. H. House. 2013. Seeding life on the moons of the outer planets via lithopanspermia. Astrobiology, 13, 1155-1165.

[39] A. R. Hildebrand. 1993. The Cretaceous / Tertiary boundary impact (or the dinosaurs didn't have a chance). Journal of the Royal Astronomical Society of Canada, 87, 77-118.

[40] L. W. Alvarez, W. Alvarez, F. Asaro and H. V. Michel. 1980. Extraterritorial cause for the Cretaceous -Tertiary extinction. Science, 208, 1095-1108.

[41] G. Keller et al. 2004. Chicxulub impact predates the K-T boundary mass extinction. Proceedings of the National Academy of Sciences, DOI:10.1073/pnas.0400396101.

[42] P. Schulte, et al. 2010. The Chicxulub asteroid impact and mass extinction at the Cretaceous-Paleogene boundary. Science, 327, 1214-1218.

[43] K. Kaiho, and N. Oshima. 2017. Site of asteroid impact changes the history of life on Earth: the low probability of mass extinction. Scientific Reports, DOI:10.1038/s41598-017141990-x.

[44] J. Brittan. 1997. Iridium at the K/T boundary - the impact strikes back. Astronomy and Geophysics, 38, 19-21.

[45] S. Donaldson, and A. R. Hildebrand. 2013. The global fluence of iridium at the Cretaceous-Tertiary boundary. $64^{\text {th }}$ Annual Meteoritical Society Meeting, 5240.pdf.

[46] J. R. Moore, et al. 2013. Iridium and osmium fluences across the K-Pg boundary indicate a small impactor. $44^{\text {th }}$ Lunar and Planetary Science Conference, 2505.pdf.

[47] P. Bland and N. A. Artemieva. 2006. The rate of small impacts on Earth. Meteoritics and Planetary Science, 41, 607-631.

[48] B. M. Simonson, and P. G. Glass. 2004. Spherule layers records of ancient impacts. Annual Review of Earth and Planetary Sciences, 32, 329-361.

[49] B. C. Johnson and H. J. Melosh. 2012. New estimates for the number of large impacts throughout Earth's history. Early Solar System Impact Bombardment II, 4027.pdf.

[50] K. A. Farley, A. Montanari, E. K. Shoemaker and C. S. Shoemaker. 1998. Geochemical evidence for a comet shower in the late Eocene. Science, 280, 1250-1253.

[51] M. F. Schaller et al. 2016. Impact ejecta at the PaleoceneEocene boundary. Science, 354, 225-229.

[52] M. Beech. 2008. Meteors over the Moon. WGN, the Journal of the IMO, 36:2, 33-36.

[53] D. Schulze-Makuch and I. A. Crawford. 2018. Was there an early habitability window for Earth's Moon? Astrobiology, 18, $1-4$.

[54] W. J. Markiewicz et al. 2014. Glory on Venus cloud tops and the unknown UV absorber, Icarus, 234, 200-203.

[55] S. S. Limaye et al. 2018. Venus' spectral signatures and the potential for life in the clouds. Astrobiology, 18, 1-18.

[56] D. S. McKay, et al. 2006. Observations and analysis of in situ carbonaceous matter in Nakhla. Lunar and Planetary Science XXXVII, 2251.pdf.

[57] G. Galletta, et al. 2009. Surviving on Mars: test with LISA simulator. Arxiv:0919.4830.

[58] R. Orosei et al. 2018. Radar evidence of subglacial liquid water on Mars. Science, DOI: 10.1126/science.aar7268. 